\title{
Understanding the Communication Strategy of Women's Rights Protection in the Digital Era through Website
}

\section{Memahami Strategi Komunikasi Perlindungan Hak Asasi Perempuan di Era Digital melalui Website}

\author{
Rahma Santhi Zinaida ${ }^{1}$, Siti Lady Havivi ${ }^{2}$ \\ ${ }^{1}$ Study Program of Communication Science, Faculty of Communication Sciences, \\ Universitas Bina Darma, Jl. Jenderal Ahmad Yani No. 3, Palembang, \\ South Sumatra 30111, Indonesia \\ ${ }^{2}$ Study Program of Communication Science, STISIPOL Candradimuka, Jl. Swadaya \\ Sekip Ujung, Palembang, South Sumatra 30164, Indonesia \\ *Corresponding author, e-mail: rahmasanthi@binadarma.ac.id
}

\begin{abstract}
The National Commission on Violence Against Women in Indonesia through their website, release that there are three women who become victims of sexual violence every two hours. Kalyanamitra was chosen as the subject of the study because there are not many NGO's committed in protecting women's rights in Indonesia that have survived for more than 33 years. This study aims to explain how the communication strategy has been done in this organization through their official website. The important of doing this study is that can inspire other NGO's to optimize the use of online media. The theories used in this study are Media Rich Theory (MRT). This study use interpretative paradigm with the type of research is qualitative descriptive. Data were collected by using content analysis from website https://www.kalyanamitra.or.id/\#. As the result, Kalyanamitra has done effective communication strategy by using techniques such as canalizing, informative, persuasive, and also educative.
\end{abstract}

Keywords: Kalyanamitra, Website, Communication Strategy, MRT.

\begin{abstract}
Abstrak
Komisi Nasional Anti Kekerasan terhadap Perempuan di Indonesia melalui website mereka, merilis bahwa ada tiga perempuan yang menjadi korban kekerasan seksual setiap dua jam. Kalyanamitra dipilih sebagai subjek penelitian karena tidak banyak LSM yang berkomitmen dalam melindungi hak-hak perempuan di Indonesia yang bertahan lebih dari 33 tahun. Tujuan penelitian ini untuk menjelaskan bagaimana strategi komunikasi telah dilakukan dalam organisasi ini melalui website resmi mereka. Pentingnya melakukan penelitian ini, bahwa dapat mengilhami LSM lain untuk mengoptimalkan penggunaan media online. Teori yang digunakan dalam studi ini adalah Media Rich Theory (MRT). Penelitian ini memakai paradigma interpretatif dengan jenis penelitiannya deskriptif kualitatif. Pengumpulan data dikumpulkan dengan analisis konten dari website https://www.kalyanamitra.or.id/\#. Untuk hasil studinya, Kalyanamitra telah melakukan strategi komunikasi yang efektif dengan melakukan teknik seperti kanalisasi, informatif, persuasif, dan juga edukatif.
\end{abstract}

Kata Kunci: Kalyanamitra, Website, Strategi Komunikasi, MRT.

\section{Introduction}

Nowadays, violence for women is an undiscovered phenomenon from the root of the solution. Global estimates published by WHO 2017 indicate that about 1 in 3 (35\%) of women worldwide have experienced either physical and/or sexual intimate partner 
violence or non-partner sexual violence in their lifetime (World Health Organization, 2017).

National Commission on Violence Against Women through its website released data that there are three women become victims of sexual violence in Indonesia every two hours. This means, every day there are approximately 35 women who become victims of sexual violence (Kementerian Sekretariat Negara RI, 2015). In its release published in Media Indonesia, recorded up to 2016, from 321,752 cases of violence against women, sexual violence in the personal realm was in the second rank, in the form of raping as much as $72 \%$ (2,399 cases), obscenity of $18 \%$ (601 cases), and 5\% sexual harassment (166 cases). As in the public domain, from the data of 5.002 cases, the highest violence against women is sexual violence (61\%) (Hemawati, 2016).

$31 \%$ cases of violence was done by unknown victims for about 5.002 case in 2016. These data show that many cases were done by the unclosest persons, this shows the lack of alertness of women to recognize people around them. Many women in Indonesia are very easy to believe in others. Based on the same data like the previous studies, violence against women is also carried out by closest people such as family, friends, spouses, colleagues and work partners. It proves that in social life there are norms that are beginning to fade away, where women who are supposed to be protected become the targets of violence. $69 \%$ women violence was done by the closest persons by 11.207 cases on 2016.

In terms of this condition, its is also our responsibility to help government in solving this problem. The emergence of Kalyanamitra as an independent women's organization during the new term government era was related to the emergence idea of the need for information center specially for women in Indonesia. Kalyanamitra becomes the second female organization born after the Anisa Swasti Foundation (Yasanti) in Yogyakarta spreading the information. Kalyanamitra uses website and social media as their platforms to introduce this organization and the ways to socialize their program and campaign (Kalyanamitra, 2018).

Kalyanamitra uses website becouse it reaches large number of people, off course like their use of social media, website gives the complete information to public. According to Hardiman, website is the collection of pages on the internet media containing information on certain topics. Usually the official company website reflects the company's identity owned and builds relationship with the public (Mukaromah \& Sari, 2016). This socialization through digital platform needs good communication strategy to attract people attention perfectly, it must not only compile all information in brief but also in attractive appearance.

Kalyanamitra was chosen as the subject of this research because there are not many NGO's commited in protecting women's rights in Indonesia that can survive for more than 33 years, how they maintain their commitment and existence through their official website. This study aims to explain how the communication strategy has been held in this organization through the official website and based on the steps of communication strategy and also why they choose website as the main medium to introduce their organization.

Rogers in Cangara (2016) defined the understanding of communication strategies as design that is made to change human behavior on larger scale through the transfer of new ideas. According to Middleton in Cangara (2016) communication strategies are the best combination of all communication elements ranging from communicators, messages, channels or media to recipients in order to affect and to achieve optimal communication 
goals. In communication field, the technique of delivering or affecting can be seen from two aspects, such as: according to the way of implementation and according to its contents (Cangara, 2016). Therefore, the first, according to the way of implementation, it can be realized in two forms, such as redundancy (repetition) and canalizing. The second, is according to the form of its contents, such as: informative, persuasive, educative, and coercive (Arifin, 1994). Some researches were done before to compare this study to the previous studies. Here are some researches that were done before related to website:

Table 1. Prior Studies (source: from many sources)

\begin{tabular}{|c|c|c|c|}
\hline No. & Researcher & Title & Year \\
\hline 1 & $\begin{array}{l}\text { Mukaromah, } \\
\text { Devi P. S. }\end{array}$ & $\begin{array}{c}\text { 'Laman dan Reputasi Lembaga dalam Membangun } \\
\text { Komunikasi dengan Stakeholders (The Page and } \\
\text { Reputation of Institutions in building Communication } \\
\text { with Stakeholders)' }\end{array}$ & 2016 \\
\hline 2 & $\begin{array}{l}\text { Vensy } \\
\text { Vydia }\end{array}$ & $\begin{array}{c}\text { 'Pemanfaatan Website sebagai Media Promosi pada } \\
\text { Fakultas Teknologi Informasi dan Komunikasi } \\
\text { Universitas Semarang (Studi Kasus pada Fakultas } \\
\text { Teknologi Informasi dan Komunikasi USM) (Use of the } \\
\text { Website as Promotion Media at the Faculty of } \\
\text { Information Technology and Communication, Universitas } \\
\text { Semarang (Case Study at the Faculty of Information } \\
\text { Technology and Communication, USM))' }\end{array}$ & 2009 \\
\hline 3 & Ati Harmoni & $\begin{array}{c}\text { 'Media Richness Theory dan Potensi Website sebagai } \\
\text { Media Komunikasi CSR oleh Perusahaan (Media } \\
\text { Richness Theory and the Potential Website as CSR } \\
\text { Communication Media by the Company)' }\end{array}$ & 2014 \\
\hline 4 & $\begin{array}{c}\text { Sumit K. } \\
\text { Lodhia }\end{array}$ & $\begin{array}{c}\text { The World Wide Web and Its Potential for Corporate } \\
\text { Environmental Communication: A Study into Present } \\
\text { Practices in the Australian Minerals Industry }\end{array}$ & 2006 \\
\hline
\end{tabular}

In order to prove that the strategy is appropriate was done by selecting website as the main medium of information delivery in addition to the use of social media and direct promotion. This study also uses Media Rich Theory (MRT) to compare the strength of socialization of kalyanamitra if done conventionally and done using digital platforms, website. This research will be a gap for research findings where almost all humans use social media as the superior platform, but website is used as the main medium for social movement strongly powered by Kalyanamitra. MRT is the most widely used theory in selection of communication media. MRT was first time introduced by Daft and Lengel which states that the use of a media is determined by its 'wealth' or richness. This MRT deals with the determination of the media as the most appropriate communication to deal with uncertainty and obscurity of information (Daft \& Lengel, 1986).

The MRT is built on the assumption that improvement 'wealth' of a media is related to social presence or physical (Zmud, Lind, \& Young, 1990). Despite the ability of the media to support a variety of communication processes contained within face-to-face context is important, there are dimensions to other media that also deserve to be taken into account. Especially innovation in the field of computer facilitated communication. (Daft \& Lengel (1984) proposed four criteria for assessing media, namely immediacy, diversity of signals, language variety, and personal source. Sproul and Valacich add more criteria such as multiple addressibility, externally recordable, computer processable memory and concurrency (Lodhia, 2006). 
Mukaromah and Sari (2016) explain that by using website, it can reflect on the reader's perception of what Udinus want to engage with people, especially in the field of education with the hope to increase the reputation of the institution. Similar to what Vydia (2009) sumarizes from her research that website is used for promotion and information to communicate the faculty to public.

Media Richness Theory has been used by Harmoni (2014). Based on the MRT framework, the use of website for companies can be a choice to communicate CSR program and website become a promising media compared to other media. Last, Lodhia (2006) research findings indicate that currently, the potential of the web is not extensively utilized by companies for environmental communication.

From the previous four researches, most of the studies are about website as the medium for building reputation, public relations and promotion in a company. The contribution of the novelty or the uniqueness make this study different from the previous studies, The important of doing this research is the content breakdowns the communication strategy technique and compares socialization in conventional way and by digital platform using website in nonprofit NGO's and the purpose of this organization is pure for social movement. Here are the concepts of this research:

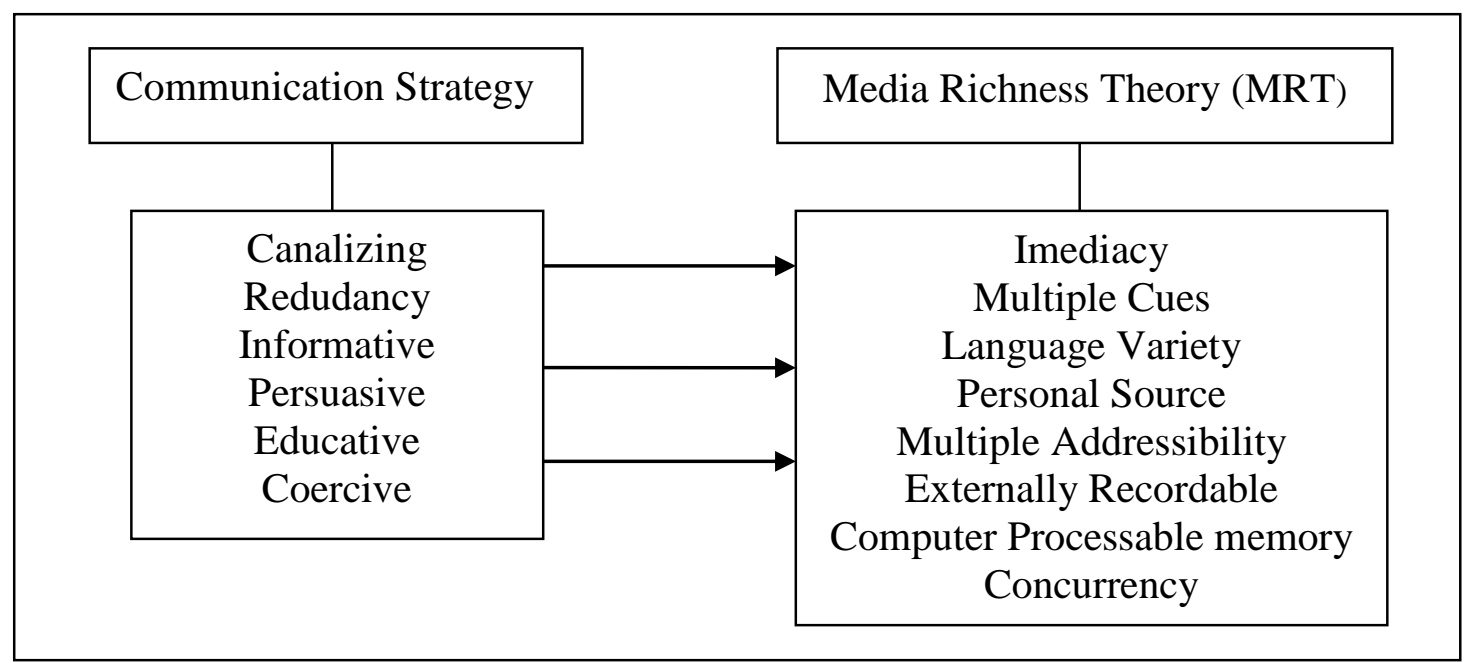

Figure 1. Concept of this research (Daft \& Lengel, 1984)

\section{Methodology}

This research belongs to interpretive paradigm because basically all research is interpretive in nature, guided by a set of beliefs and feelings of the researchers towards the world and how to understand and study them. Each interpretive paradigm raises certain demands on the researchers, which include the questions posed and interpretations applied to them (Denzin \& Lincoln, 2011).

Qualitative was chosen as the research approach in this study. This type of qualitative research is intended to express the picture or the understanding of how and why a phenomenon or reality of communication occurs (Pawito, 2007). The scope of this research focused on website analysis http://kalyanamitra.or.id. In this study, the researchers used several theoretical reviews of Media Rich Theory (MRT) and communication strategy techniques (redundancy, canalizing, informative, persuasive, educative and coersive). The data collection method used observation as primary data in this research. After collecting the data, the next step was data validity technique using triangulation technique. 


\section{Results and Discussion}

Kalyanamitra was established on 28 March 1985 in response to the injustices faced by Indonesian women at that time. The name Kalyanamitra comes from Sanskrit language, which means 'Good Friend'. Kalyanamitra was founded by five women: Ratna Saptari, Debra Yatim, Sita Aripurnami, Myra Diarsi, and Syarifah Sabaroeddin. At the beginning of its establishment, Kalyanamitra wanted to support the work of various parties in the strengthening of labor by providing information about labor rights, that workers deserve the same wages, are entitled to menstruation leave, maternity leave and childbirth. To that end Kalyanamitra sided with oppressed women such as laborers, farmers, fishermen, and informal sector workers. Therefore, Kalyanamitra collected data on various aspects of women and raised them to the surface through seminars, training, and public discussions.

Data on various aspects of women from the feminist perspective are collected in Kalyanamitra's library in various forms such as books, working papers, research reports, videos, photos and slides documenting women's lives. In 1993, Kalyanamitra became the resource center which was divided into two divisions of work namely Development Research Division and Library Division. Activities undertaken are research on women worker issues in Kramat Jati Market, Domestic Workers, prostitution, rape, sexual harassment, and others. The results of the study were raised and socialized to the community. Kalyanamitra uses the online mass media website to educate, to persuade people both women and men, to know and to realize the rights of women who are protected, not only by the government of Indonesia, but also protected by the international world through UN Woman, the United Nations and others.

Why use online media? The fact is that internet users in Indonesia are increasing drastically every year. According to the Association of Internet Service Provider Indonesia (AISPI), currently there are 88.1 million internet users in Indonesia indicates that about $34.9 \%$ of Indonesian citizens are able to access internet. As many as $49 \%$ of internet users in Indonesia ranged between the ages of 18 to 25 years and as many as $87.4 \%$ use internet to access social media. The majority of users accesses the internet at home. From the data above, it can be concluded that the majority of social media and online media users is the teenager to the early adult. At that time, the role of peers is an important aspect in adolescent life. Person who has high social competence tends to avoid behavior that is not socially acceptable. That's why they rarely take actions that harm others.

According to the National Commission on the Protection of Women, One step to prevent and to deal with sexual violence is to support the work of NGO's for the victims of women violence such as Kalyanamitra by collecting information about sexual violence that is happening around us (Adi, 2010). This study was conducted in the Year 2017 until 2018. The website is changed periodicaly for updating data, socializing new progam and the appearence. To analyze the contents of this Kalyanamitra website needs some theoretical blade that will be discussed below. Based on the result of the analysis using techniques of communication (redundancy, canalizing, informative, persuasive, educative and coercive) and the result analyzed with cultural norm theory with specific ways referred to are reinforced the existing patterns, create new shared convictions, and change the existing norms. Here is the result: 
Table 2. Kalyanamitra Communication Strategy through Website (Arifin, 1994)

\begin{tabular}{cc}
\hline \multirow{2}{*}{ Canalizing } & Kalyanamitra Strategy \\
\cline { 2 - 3 } & $\begin{array}{c}\text { Held gathering, seminar, workshop, online discussion, all } \\
\text { reports from this event can be easilly downloaded in website } \\
\text { Building community networking, advocation, } \\
\text { Redudancy } \\
\text { accompaniment of victims report. All information are also } \\
\text { shared in social media youtube, instagram, facebook and } \\
\text { twitter, so it's more easy to reach public. } \\
\text { Informative } \\
\text { Spreading news, news linked, e-journal, e-book, annual } \\
\text { report, media analysis, all documents are free to be } \\
\text { downloaded and shared on the website }\end{array}$ \\
Persuasive $\quad \begin{array}{c}\text { Categorizing the page, each pages is easy to read and share } \\
\text { on website. Using cartoon, picture, persuasive words in } \\
\text { making a campaign. }\end{array}$ \\
$\begin{array}{c}\text { Using video, poster, advocation, e-library, e-book, research } \\
\text { report, media analysis can be downloaded in the website }\end{array}$ \\
\hline
\end{tabular}

The first technique is redundancy. This is a technique to persuade the audiences by repeating messages to the audiences. Kalyanamitra channel is one of the services on this website to display persuasive and informative videos about women's world information, such as video documentation of Kalyanamitra activities such as seminars, discussion documentation, workshops, news coverage about women, sexual violence against women series, around CEDAW which is International Law regulating women's rights regulated by UN CEDAW committee.

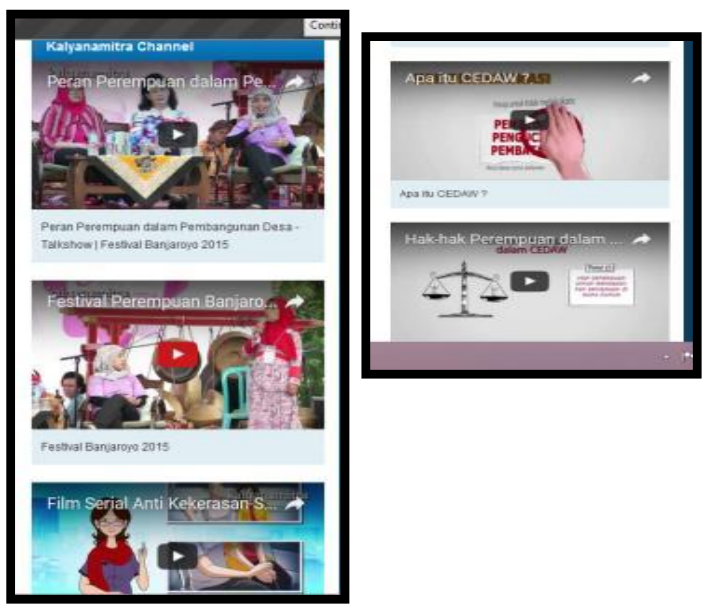

Picture 1. Kalyanamitra Channel

(source: Kalyanamitra, 2018)

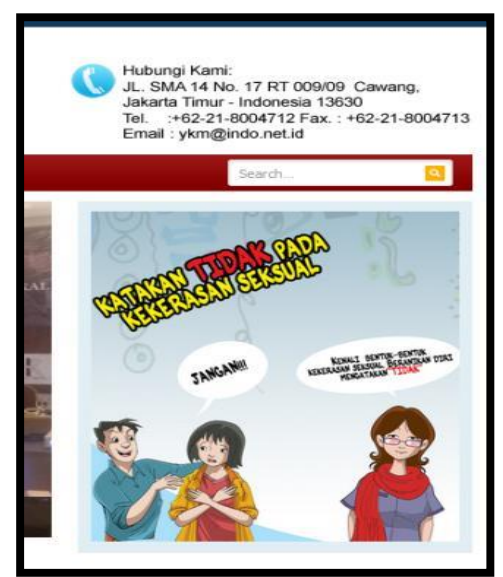

Picture 2. Non sexual Violence poster (source: Kalyanamitra, 2018)

As we seen in the picture 1 and 2 above, human as visual creatures can easily accept information by seeing something that is 'alive', moving and speaking. To communicate the idea more effectively, presentation in the form of video is needed to present the moving image and sound as needed. Kalyanamitra tries to introduce their organization with video so it will be more effectively understood by people rather than just reading the explanation by words.

The channel can be watched over and over again so that they can affect people and educate women that their rights as women are protected by the world, so sexual violence, abusement and other crimes can be avoided because the awareness of women can be improved and women's confidence increases. On the other hand, men who are the biggest 
object of perpetrators of violence against women are aware of CEDAW law and rethink if they want to commit acts of violence to women. The created video also uses simple but clear animation technology in the delivery of its message to the public because it uses daily language that is easy to understand.

Kalyanamitra uses canalizing technique by making poster. Canalizing is the activity of understanding a community or group and gradually affect the idealism of the group and if it is difficult then the group's confidence must be solved so that the group's influence will be depleted and may accept new influences. On this website, there is no doctrine to the audiences, but socialization tools such as posters that continue to assert anti-sexual violence continue to be updated and installed with larger size and other contents. The process of canalizing done by Kalyanamitra is by using poster that can be seen on this website in the first page. Poster can be seen on picture 2 above.

Poster is the effective outdoor media to persuade the public, Posters are also known as publications consisting of writing, images or combination of the two with the aim of providing information to the general public. Posters are usually installed in public places that are considered strategic such as schools, offices, markets, malls and other public places. Information on posters generally invites and persuades public. On this website, there is also poster of anti-sexual violence that is quite unique. Using cartoon as media that is easilly to remember and to be careful with the words say 'NO' to sexual violence.

As visual communication tools, cartoon is interpretive images that use symbols to convey message quickly and succinctly, or an attitude towards certain people, situations, or events. Cartoons usually only reveal the essence of the message that must be conveyed and pour it into simple images, without details, using symbols and characters that are easily recognized and quickly understood. Cartoons have interesting side that has more advantages compared to other visual communication media. Cartoons as comics are multi purpose usefull media because the existence of cartoons does not only present entertainment from humor contained in it but also has a variety of other functions (Zpalanzani, Ahmad, \& Maulana, 2006) including: cartoon as cheap entertainment media, as medium for storytelling, educational media, cultural change, media for expression, exploitation and propaganda.

Kalyanamitra wants to take the use of educational medium by using cartoon to persuade people regarding the message of against woman violence. In the poster below it looks visually appealing to the interesting color, the slogan "Say No On Sexual Violence" is straight to the point on the message from Kalyanamitra itself. It also more flexible to send the message of this poster, easy to accept, also easy to understand by young people like teenagers.

The next technique used is informative communication, Some forms of publication of communication strategies conducted by http://www.kalyanamitra.or.id/ are news content, publication of annual reports, media analysis publications, women's studies, news content, news or research news coverage. The form of message content that can illuminate the intent and purpose of communication strategy is an element of information.

The information presented on this website is complete, prioritizing news about sexual violence in women, around women's rights legislation, penalties for perpetrators of sexual violence for women, etc. This news can be cited from various news sources such as print media, electronic media, other online media. Here are some news functions for audiences in daily life: The news posted on Kalyanamitra's website contains news about the development of women's rights protection, government regulations on women, 
criminal news about violence against women and others. This information is important to educate the public, especially women, to further enhance self-awareness and belief.

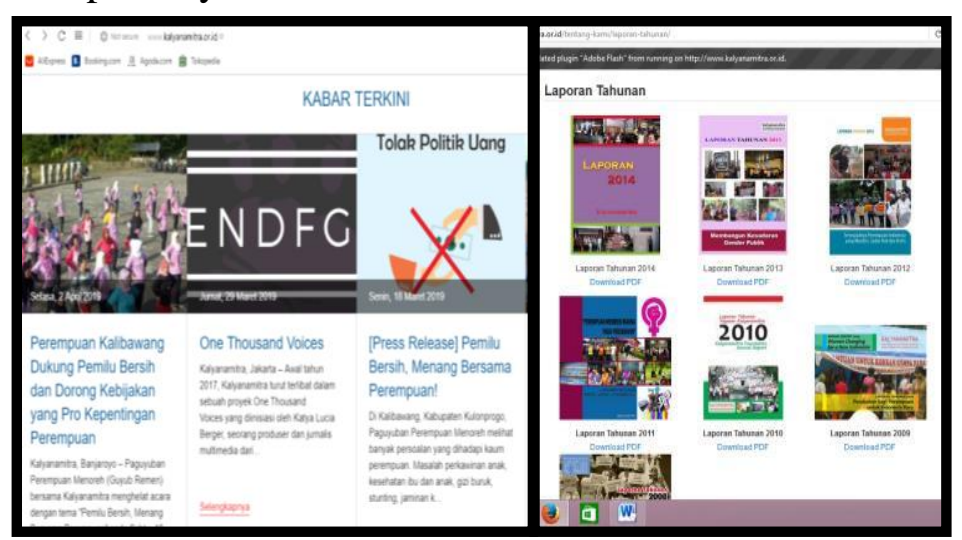

Picture 3. News Content and Annual report in Kalyanamitra website (source: Kalyanamitra, 2018)

On the page 'Tentang Kami' (About Us) on Kalyanamitra website promotes the Annual Report of Kalyanamitra's Activities from 2008-2018. This shows the seriousness of this institution to become the center of communication and information for every women, especially focused on women's sexual violence. In the hope to build people's trust, public can see Kalyanamitra's effort to present in their annual report a complete version every year.

This Annual Report becomes an informative communication because there is full service of information about activities, donations, fund raising, books, videos, cooperation with other agencies or government, the number of product sales from catalogues, the addition of books, newspaper clippings/media, PR activities, serving articles in their digital libraries, an international news, and many more. This information becomes important for the community because Kalyanamitra is very transparent in running its program that can be seen periodically. Communication strategy using the annual report published in webiste media will be an effective communication strategy to Kalyanamitra socialization to keep geting more attention from public, the government and the international world.

Kalyanamitra also runs media analysis, this activity is in line with the concept of communication strategy where media is the tool of information, dissemination, and promotion, but always seen from two sides, negative and positive. So, it needs some filters and analysis of writing in the media. It is very necessary to observe the news about women female migrant workers, Indonesian migrant workers, especially women. The next technique is to set persuasive communication that is derived from the term persuasion. While the term; 'Persuasion', the verb is to persuade, which can be interpreted as persuading, seducing, convincing, and so on (Widjaja, 2010). It can be interpreted as the attempt to convince others to act and to behave as the communicator expected by persuading without force and violence.

Current communication persuasion is not the new thing anymore and this technique is quite effective to change people's opinion about something new. For example, among artists and the military, without realizing it, they have carried out persuasion as the attempt to achieve certain goals in communicating with the public or their fans (Widjaja, 2010). Kalyanamitra has astrategy to persuade public by using their website which can be categorized as persuasion activity by providing 7 (seven) page columns, each of which present concise and detailed content with complete description. Bulletin is also 
created and published by Kalyanamitra in their website. Mitra Media newsletter and the bulletin called 'Dongbret', were published in the form of pictorial story inserts which can be easily understood. However, in 1994, during the prohibition of Tempo and Detik, Mitra Media were also banned from publishing by the Government at that time. In 1991, as part of Anti-Rape Campaign, Kalyanamitra also published a pocket book on handling rape cases.

Furthermore, Kalyanamitra newsletter changed its name to 'Bejana Wanita' in 1996 and 'Bejana Perempuan' in 2000. Later in 2005 Kalyanamitra published 'Bulletin Kalyanamedia' and changed its name into 'Bulletin Wanita Bergerak' in 2008 until today. This newsletter and bulletin serve as customer relations for community relations where the readers of this website or members of ta mia from Kalyanamitra can see the information about kalyanamitra's activities and are indirectly influenced psychologically to keep on listening to the contents of this website or Kalyanamitra institute. The making of this newsletter and bulletin are the effective steps in persuading people because of the personal involvement of one person with an organization/institution. If someone receives newsletters and bulletins in digital format/enewsletters sent to their emails, they will feel apart from Kalyanamitra itself.

There are also a catalog service to persuade the community to help others devoted to run some programs of anti-violence or violence against women by donating some of their wealth by purchasing products which are produced by Kalyanamitra. How to persuade using multi functional product brands (brand equity) such as T-shirts, hats, mugs, bags, Video CDs and others will also be the company awareness strategy, as long as the product is used, carried, then indirectly will be the promotion media for Kalyanamitra in the community. For education strategy, the library becomes the important thing because Kalyanamitra wants to be the Women's Information and Communication Center. The Kalyanamitra library also has collection of clippings on women's issues in the mass media since 1996. Besides the library, Kalyanamitra also has an education program on gender analysis training for non-governmental activists. It can be said that Kalyanamitra introduced gender analysis training in Indonesia in 1990.

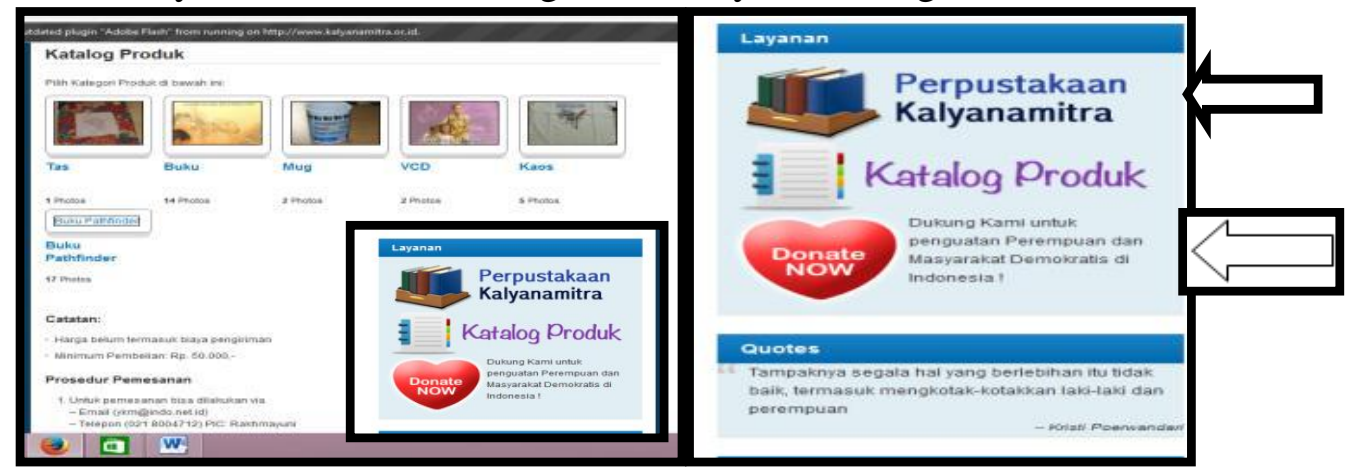

Picture 4. Catalogue and Online Library Products (source: Kalyanamitra, 2018)

In order to provide knowledge and awareness on women's issues to the public, Kalyanamitra publishes various publications including books, bulletins, posters, pamphlets and so on. In addition to the bulletin, Kalyanamitra also publishes several books on women such as 'Menghadapi Pelecehan Seksual' (1999), 'Bila Perkosaan Terjadi' (2000), 'Gerakan Perempuan dan Kesadarannya' (2001), 'Ibunda' (2002), 'Gerakan Perempuan di Amerika Latin: Feminisme dan Transisi Menuju Demokrasi' (2003), 'Asal Usul Keluarga, Kepemilikan Pribadi dan Negara' (2004), 'Berbagi Pengalaman', 'Merajut Perlawanan: Tuturan Survivor' (2007), 'Evolusi Perempuan: 
Dari Klan Matriarkal Menuju Keluarga Patriarkal' (2011), and many more (http://www.kalyanamitra.or.id/). In addition to libraries, there is also donation service for the donors or the general public who wish to participate in helping the Kalyanamitra social movement to help victims of violence and to prevent violence happens to women, even more. Kalyanamitra does not use hard persuasive in communicating their organizations. All activities of communication strategy are applied to positive elements of informing, educating and inviting. So there is no coercive element in the communication strategy applied.

Here are the comparation between using the conventional strategy of socialization and using the website:

Table 3. Kalyanamitra Web and MRT (Harmoni, 2014)

\begin{tabular}{|c|c|c|}
\hline & Conventional & Web \\
\hline Imediacy & $\begin{array}{l}\text { Limited to standard } \\
\text { information }\end{array}$ & $\begin{array}{l}\text { Vision and mission can be updated } \\
\text { everytime, every news or information can } \\
\text { be updated more easily }\end{array}$ \\
\hline Multiple Cues & $\begin{array}{l}\text { Printed poster must take } \\
\text { in the office or send by } \\
\text { post, will take more time } \\
\text { and money }\end{array}$ & $\begin{array}{l}\text { All media such as e-poster, video and other } \\
\text { cues can be downloaded and shared easily }\end{array}$ \\
\hline $\begin{array}{l}\text { Language } \\
\text { Variety }\end{array}$ & Ussually formal & $\begin{array}{l}\text { Using cartoon, easy words, easy to } \\
\text { understand and to remember }\end{array}$ \\
\hline Personal Source & $\begin{array}{l}\text { General information for } \\
\text { public }\end{array}$ & $\begin{array}{l}\text { Segmented, as user of website, we can } \\
\text { search information based on what we need }\end{array}$ \\
\hline $\begin{array}{c}\text { Multiple } \\
\text { Addressibility }\end{array}$ & $\begin{array}{l}\text { General accessibility is } \\
\text { limited due to the } \\
\text { obstacles like Geography } \\
\text { or accesability }\end{array}$ & $\begin{array}{l}\text { Everyone who can access the web can get } \\
\text { information because global affordability } \\
\text { and the potential for mass communication }\end{array}$ \\
\hline $\begin{array}{l}\text { Externally } \\
\text { Recordable }\end{array}$ & $\begin{array}{l}\text { It is usually served in } \\
\text { printed and available } \\
\text { only at the office, } \\
\text { sometimes need a long } \\
\text { process to even just ask } \\
\text { for a copy }\end{array}$ & $\begin{array}{c}\text { All collection like e-library, e-book, e- } \\
\text { manuscript, e-journal, research report, } \\
\text { news letter, e-magazine are free to } \\
\text { download }\end{array}$ \\
\hline $\begin{array}{l}\text { Computer } \\
\text { Processable } \\
\text { memory }\end{array}$ & Manual searching & $\begin{array}{l}\text { Easy to find in every browser or find } \\
\text { machine, social media, youtube }\end{array}$ \\
\hline Concurrency & $\begin{array}{l}\text { The process to get } \\
\text { feedback is quite limited. } \\
\text { Simultaneous interaction } \\
\text { is imposible }\end{array}$ & $\begin{array}{c}\text { Communication and advocacy assistance, } \\
\text { Online FGD }\end{array}$ \\
\hline
\end{tabular}

\section{Conclusion}

As explained in the discussion above, Kalyanamitra has done many strategies to communicate their organization for one purpose, to protect Indonesian women from violence. Based on several techniques in communication strategy, that Kalyanamitra did 
not conduct the coercive technique because they did not do hard persuasive. Here is the sumarize displayed in a table:

Table 4. Communication Strategy technique applied in Kalyanamitra Website

\begin{tabular}{|c|c|c|}
\hline & Kalyanamitra Website & Communication Strategy Technique \\
\hline Imediacy & $\begin{array}{l}\text { Vision and mission can be } \\
\text { updated every time, every } \\
\text { news or information can be } \\
\text { updated more easily }\end{array}$ & $\begin{array}{c}\text { Canalizing technique: Informastion is } \\
\text { always updated, website is also } \\
\text { updated every year }\end{array}$ \\
\hline $\begin{array}{l}\text { Multiple } \\
\text { Cues }\end{array}$ & $\begin{array}{l}\text { All media such as e-poster, } \\
\text { video and other cues can be } \\
\text { downloaded and shared easily }\end{array}$ & $\begin{array}{l}\text { Educative technique: Using video, } \\
\text { poster, advocation, e-library, e-boork, } \\
\text { research report, media analysis can be } \\
\text { downloaded in website }\end{array}$ \\
\hline $\begin{array}{l}\text { Language } \\
\text { Variety }\end{array}$ & $\begin{array}{c}\text { Using cartoon, easy words, } \\
\text { easy to understand and to } \\
\text { remember }\end{array}$ & $\begin{array}{c}\text { Persuasive technique: Using cartoon, } \\
\text { picture, persuasive words in making a } \\
\text { campaign }\end{array}$ \\
\hline $\begin{array}{l}\text { Personal } \\
\text { Source }\end{array}$ & $\begin{array}{c}\text { Segmented, as the user of the } \\
\text { website, we can search } \\
\text { information based on what } \\
\text { we need }\end{array}$ & $\begin{array}{l}\text { Persuasive technique: Categorizing } \\
\text { the page, each page is easy to read and } \\
\text { to share on website }\end{array}$ \\
\hline $\begin{array}{c}\text { Multiple } \\
\text { Addressibility }\end{array}$ & $\begin{array}{l}\text { Everyone who can access the } \\
\text { web can get information } \\
\text { because global affordability } \\
\text { and the potential for mass } \\
\text { communication }\end{array}$ & $\begin{array}{c}\text { Canalizing technique: Information are } \\
\text { easy to share and to distribute to the } \\
\text { right segmentation }\end{array}$ \\
\hline $\begin{array}{l}\text { Externally } \\
\text { Recordable }\end{array}$ & $\begin{array}{l}\text { All collection like e-library, } \\
\text { e-book, e-manuscript, e- } \\
\text { journal, research report, news } \\
\text { letter, e-magazine are free to } \\
\text { download }\end{array}$ & $\begin{array}{l}\text { Informative technique be: Spreading } \\
\text { news, news linked, e journal, e book, } \\
\text { annual report, media analysis, all } \\
\text { documents are free to download and } \\
\text { to share on the website }\end{array}$ \\
\hline $\begin{array}{l}\text { Computer } \\
\text { Processable } \\
\text { memory }\end{array}$ & $\begin{array}{c}\text { Easy to find in every browser } \\
\text { or finding machine, social } \\
\text { media, youtube }\end{array}$ & $\begin{array}{c}\text { Redudancy technique: All information } \\
\text { are also shared in social media } \\
\text { youtube, instagram, facebook and } \\
\text { twitter, so it's more easy to reach } \\
\text { public }\end{array}$ \\
\hline Concurrency & $\begin{array}{c}\text { Communication and } \\
\text { advocacy assistance, Online } \\
\text { FGD }\end{array}$ & $\begin{array}{l}\text { Redundancy technique: Building } \\
\text { community networking, advocation, } \\
\text { accompaniment of victims report }\end{array}$ \\
\hline
\end{tabular}

The conclusion that can be drawn from the analysis of communication strategy is that Kalyanamitra has already done it well and effectively. In this study, the researchers used several theoretical reviews of MRT (immediacy, multiple cues, language variety, personal source, multiple addressibility, externally recordable, computer processable memory, concurrency) and communication techniques (redundancy, canalizing, informative, persuasive, educative and coercive). From the analysis, redundancy technique used by Kalyanamitra were channel (video and slide) and poster of Anti Sexual Violence. Canalizing technique is applied because information is always updated, website is also updated every year. Informative technique uses news content, annual reports, and 
publication of media analysis, whereas persuasive technique uses mitra media and Kalyanamitra Bulletin.

To educate people Kalyanamitra uses library and donation. Kalyanamitra did not use coercive technique in their website. Regarding the MRT, the result describes that the reason Kayanamitra chooses website as the main media is to personalize their organization identity and program because as stated in immediacy vision and mission of Kayanamira, it can be updated every time, every news or information can be updated more easily, many multiple cues are displayed on every page, they also use many language variety like using cartoon, picture, short story, video, creative quote and many others. The website tools also help people to track the information based on personal need. Everyone who can acces the web can get information because of the global affordability and the potential for mass communication. External recording criteria is related to the ability of the media to provide communication recordings, including the ability to keep the document and also modify the communication process.

All the communication criteria and process conducted by Kalyanamitra through their website as the main media for promotion are appropriate in the selection of media, but the program socialization process indeed will be far more effective if it is not only done online but also carried out offline. Face-to-face events and activities are needed, the target must also be segmented and the program provided is not only education for women but also socialization for men, so that they will understand about women's rights and how to treat women as well.

\section{Acknowledgements}

The researchers would like thank to the National Commission on Violence Against Women, Kalyanamitra, and all resources.

\section{References}

Adi. (2010). 11 Bentuk Kekerasan Seksual pada Perempuan. Retrieved from 24 November 2010 website: https://m.viva.co.id/berita/metro/190382-11-kekerasanseksual-terhadap-perempuan

Arifin, A. (1994). Strategi Komunikasi, Sebuah Pengantar Ringkas. Bandung: CV. ARMICO.

Cangara, H. (2016). Komunikasi Politik: Teori, Konsep dan Strategi (Edisi Revisi). Jakarta: Rajawali Pers.

Daft, R., \& Lengel, R. (1984). Information richness: a new approach to managerial behaviour and organization Design. Research in Organizational Behaviour, 6, 191233.

Daft, R., \& Lengel, R. (1986). Organizational Information Requirements, Media Richness and Structural Design. Journal of Management Science, 32(5), 554-571.

Denzin, N. K., \& Lincoln, Y. S. (2011). The SAGE Handbook of Qualitative Research 1 (3rd ed.). Yogyakarta: Pustaka Pelajar.

Harmoni, A. (2014). Media Richness Theory dan Potensi Website sebagai Media Komunikasi CSR oleh Perusahaan. Gunadarma University Repository. Retrieved from http://repository.gunadarma.ac.id/1303/

Hemawati, R. (2016). Percepat Perlindungan Perempuan. Retrieved from 04 May 2016 website: http://mediaindonesia.com/news/read/43753/percepat-perlindunganperempuan/2016-05-04

Kalyanamitra. (2018). Kalyanamitra. Retrieved March 20, 2019, from 2018 website: 
http://www.kalyanamitra.or.id

Kementerian Sekretariat Negara RI. (2015). Perlindungan Perempuan dari Ancaman Kekerasan Seksual. Retrieved March 20, 2019, from 26 May 2015 website: http://www.presidenri.go.id/berita-aktual/perlindungan-perempuan-dari-ancamankekerasan-seksual.html

Lodhia, S. K. (2006). The World Wide Web and Its Potential for Corporate Environmental Communication: A Study into Present Practices in the Australian Minerals Industry. The International Journal of Digital Accounting Research, 6(11), 65-94.

Mukaromah, \& Sari, D. P. (2016). Laman dan Reputasi Lembaga Dalam Membangun Komunikasi dengan Stakeholders. Jurnal The Messenger, 8(2), 35-42. Retrieved from http://journals.usm.ac.id/index.php/the-messenger/article/view/341/231

Pawito. (2007). Penelitian Komunikasi Kualitatif. Yogyakarta: LKIS.

Vydia, V. (2009). Pemanfaatan Website Sebagai Media Promosi Pada Fakultas Teknologi Informasi dan Komunikasi Universitas Semarang (Studi kasus pada fakultas teknologi informasi dan komunikasi USM). Jurnal The Messenger, 1(1), 42-47.

Widjaja, H. A. (2010). Komunikasi, Komunikasi \& Hubungan Masyarakat. Jakarta: Bumi Aksara.

World Health Organization. (2017). Violence against women. Retrieved March 20, 2019, from 29 November 2017 website: https://www.who.int/news-room/factsheets/detail/violence-against-women

Zmud, R., Lind, M., \& Young, F. (1990). An Attribute Space for Organizatonal Communication Channels. Journal Information Systems Research, 1(4), 440-457. https://doi.org/https://doi.org/10.1287/isre.1.4.440

Zpalanzani, A., Ahmad, H., \& Maulana, B. (2006). Histeria! Komikita: Membedah Komikita Masa Lalu, Sekarang, Dan Masa Depan. Jakarta: PT Elex Media Komputindo. 